\title{
The influence of SiC particle size on mechanical properties of aluminium matrix composites
}

\author{
Wpływ wielkości cząstek fazy umacniającej SiC \\ na właściwości mechaniczne kompozytów \\ na osnowie aluminium
}

\begin{abstract}
The main aim of this study was to determine the influence of SiC particle size on the mechanical properties of aluminum matrix composites. The reinforcing phase was introduced into the aluminum matrix in two different particle sizes: a coarse fraction with particle size ranging from 40 to $60 \mu \mathrm{m}$, and a fine fraction with particle size of less than $2 \mu \mathrm{m}$. The SiC particles were added in various quantities equal to $2.5,5,7.5$, and $10 \mathrm{wt} \%$ in order to determine the influence of different contents of the reinforcing phase on the density, hardness, and compressive strength of the obtained composite materials. By using scanning electron microscopy (SEM), the microstructure observations were performed and allowed for defining the influence of matrix/reinforcement particle size ratio (PSR) on the distribution of reinforcement particles in the matrix. The $\mathrm{Al}-\mathrm{SiC}$ composites were prepared through the conventional powder metallurgy technique, including compaction under a pressure of $300 \mathrm{MPa}$ and a sintering process in a nitrogen atmosphere at $600^{\circ} \mathrm{C}$. Applying the reinforcing phase with the particle size $(40-60 \mu \mathrm{m})$ similar to matrix $(<63 \mu \mathrm{m})$ allowed us to obtain a more-uniform distribution of $\mathrm{SiC}$ particles in the matrix than after introducing the fine fraction of reinforcement $(2 \mu \mathrm{m})$. The mechanical properties of the Al-SiC composites increased with increases in the weight fraction of the reinforcing phase, wherein this effect is more visible for composites reinforced with $\mathrm{SiC}$ particles of finer gradation.
\end{abstract}

Keywords: aluminum matrix composites, particle size ratio (PSR), powder metallurgy, silicon carbide, compression test

\section{Streszczenie}

Celem badań było określenie wpływu wielkości cząstek fazy umacniającej SiC na właściwości mechaniczne kompozytów na osnowie aluminium. Do aluminiowej osnowy wprowadzono fazę

Anna Wąsik M.Sc. Eng., Beata Leszczyńska-Madej D.Sc. Ph.D. Eng.: AGH University of Science and Technology, Faculty of Non-Ferrous Metals, Department of Materials Science and Non-Ferrous Metals Engineering, Krakow, Poland, Marcin Madej Ph.D. Eng.: AGH University of Science and Technology, Faculty of Metals Engineering and Industrial Computer Science, Department of Physical and Powder Metallurgy, Krakow, Poland; anntylek@agh.edu.pl 
SiC o różnej wielkości cząstek, tworzących tzw. frakcję drobną $(2 \mu \mathrm{m})$ oraz grubą $(40-60 \mu \mathrm{m})$. Celem zbadania wpływu zawartości cząstek węglika krzemu w osnowie na gęstość, twardość oraz wytrzymałość na ściskanie otrzymanych kompozytów udział wagowy cząstek SiC określono odpowiednio na poziomie: 2,5; 5; 7,5 oraz 10\% wag. Przeprowadzono również obserwacje mikrostrukturalne przy użyciu skaningowego mikroskopu elektronowego (SEM), które pozwoliły na określenie wpływu stosunku wielkości cząstek materiału osnowy oraz fazy umacniającej na rozkład cząstek SiC w aluminiowej osnowie. Materiał został wytworzony metodą konwencjonalnej metalurgii proszków, obejmującą proces prasowania pod ciśnieniem 300 MPa oraz spiekania w atmosferze azotu w temperaturze $600^{\circ} \mathrm{C}$. Zastosowanie cząstek fazy umacniającej o wielkości (40-60 $\mu \mathrm{m})$ zbliżonej do rozmiaru cząstek materiału osnowy $(<63 \mu \mathrm{m})$ pozwoliło uzyskać bardziej równomierny rozkład cząstek fazy umacniającej SiC w osnowie niż w przypadku wprowadzenia cząstek SiC o drobnej frakcji (poniżej $2 \mu \mathrm{m}$ ). Właściwości mechaniczne kompozytów Al-SiC wzrosły wraz ze wzrostem udziału wagowego fazy umacniającej, przy czym efekt ten jest bardziej widoczny w przypadku umocnienia cząstkami SiC o mniejszej gradacji.

Słowa kluczowe: kompozyty na osnowie aluminium, stosunek wielkości cząstek (SWC), metalurgia proszków, węglik krzemu, ściskanie

\section{Introduction}

Aluminum metal matrix composites (MMC) are promising materials for aerospace, automotive, and electronic applications due to their high specific strength, wear resistance, and attractive thermal properties [1].

The silicon carbide $(\mathrm{SiC})$ particles introduced to the aluminum metal matrix have a significant influence on the mechanical properties. The correlations between the contents of the $\mathrm{SiC}$ reinforcement phase and mechanical properties have been investigated by a large number of authors [2-4]. It is well-known that a higher amount of SiC phase successfully improves the strength, hardness, and wear resistance of the aluminum matrix. The strengthening mechanism is obtained directly by the load transformation from the matrix to hard $\mathrm{SiC}$ particles, which results in inhibiting the movement of the dislocations. Independent from manufacturing methods (stirring casting or powder metallurgy), the main aim is to provide a uniform distribution of the strengthening phase in the matrix.

The particle size of reinforcement and matrix - PSR (Particle Size Ratio) has a strong effect on the microstructure and mechanical aspects of MMC. PSR is a significant factor responsible for the homogeneous distribution of the strengthening phase in the matrix, especially in the case of using the powder metallurgy technique. The clusters of fine $\mathrm{SiC}$ particles in-between the larger aluminum grains (and also the coarse fraction of SiC particles in the aluminum matrix) might cause voids and, thus, can be treated as crack initiation points. In this case, particle reinforcement is not effective and leads to a decrease in mechanical properties [5].

In patent (US 6972109 B1) [6], the authors described the method of improving the tensile properties of Al-SiC composites. According to them, decreasing the PSR between 
the matrix and reinforcement (from 8 to $2 \mu \mathrm{m}$ ) caused an increase in the homogeneity of distribution of the $\mathrm{SiC}$ particles.

El-Kady et al. [5] also studied the effect of the PSR on the mechanical properties of Al-SiC composites. Lower PSR was correlated with lower porosity and more-homogenous reinforcing phase distribution in the matrix. However, increasing the reinforcement particle size might also cause a deterioration of mechanical properties due to the high stress accumulation.

\section{Experiments}

In our experiments, widely-used aluminum matrix composites were prepared through the conventional powder metallurgy technique. Silicon carbide particles were used as reinforcement, with average diameters ranging between 40and $60 \mu \mathrm{m}$ (coarse fraction) and less than $2 \mu \mathrm{m}$ (fine fraction). The aluminum powder had an average particle size of $63 \mu \mathrm{m}$ and $99.7 \%$ purity. The weight fraction of the SiC particles in the composites was equal to $2.5,5,7.5$, and $10 \mathrm{wt} \%$. Figure 1 shows a scanning electron microscopy (SEM) image of the powder particles. SEM revealed the globular shape of the aluminum powder (Fig. 1a) and angular shapes of the micrometric ceramic particles (Fig. 1b and 1c). The powders were blended mechanically using a Turbula T2F mixer. After being mixed, the aluminum powder with various amounts of $\mathrm{SiC}$ particles was put into a rigid die and pressed at a compaction pressure of $300 \mathrm{MPa}$ and then sintered at $600^{\circ} \mathrm{C}$ in a nitrogen atmosphere for one hour. To achieve the uniform distribution of reinforcement particles in the matrix (and additionally to reduce porosities), the compacting and sintering procedures were repeated.

a)

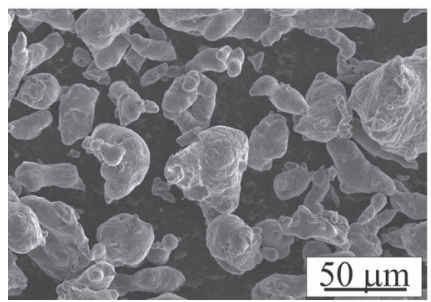

b)

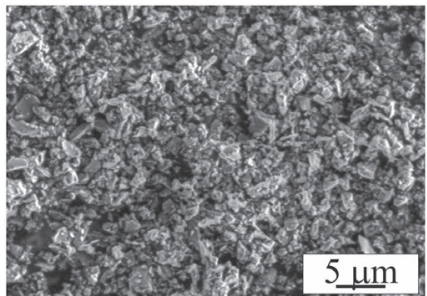

c)

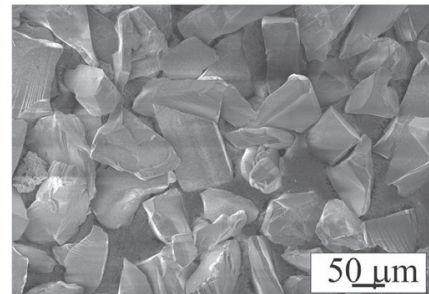

Fig. 1. SEM micrographs of starting powders of: a) Al powder with $63 \mu \mathrm{m}$ particle size; b) SiC powder with $2 \mu \mathrm{m}$ particle size; c) SiC powder with 40-60 $\mu \mathrm{m}$ particle size

The densities of the composites were determined by the geometric method and compared with theoretical densities to obtain the degree of densification and volume of porosity. The microstructure of the prepared composites was studied with a Hitachi Su 70 
scanning electron microscopy to determine the distribution of $\mathrm{SiC}$ particles in the matrix. The hardness of both the pure aluminum matrix and reinforced composites was determined through the Brinell indentation technique using a $2.5-\mathrm{mm}$-diameter carbide ball with a load of $62.5 \mathrm{kG}$.

The compression tests were performed at room temperature on a universal testing machine (Zwick Roell Z050) at an initial strain rate of $8 \cdot 10^{-3} \mathrm{~s}^{-1}$. The compressive strength and yield stress of the samples were determined based on engineering stress referring to the initial specimen dimension. According to the standard compression tests for metals given in ASTM E-9, it is recommended that the specimens used in the test should not have large length to diameter ratio (L/D) in order to avoid its buckling during deformation, and this should be equal to 1.5 for short samples. However, in this study, the specimens prepared for the compression test were cylindrical with an L/D ratio equal to 1.2. This is associated with the chosen technique of preparation for the Al-SiC composites. During compaction, the pressure decreases as the distance from the surface of the stamp increases due to the loss of part of the pressure on the friction between each powder particle and the die. The result is an uneven distribution of density in the green compact. As the composites were obtained applying conventional powder metallurgy methods, the powders were pressed on a single-action compaction press. Thus, the highest density is obtained in the upper layers adjoined to the stamp during pressing. Density distribution in the green compact is determined by its dimensions; therefore, the smaller the L/D ratio, the more-uniform the density distribution will be obtained in the green compact. Increasing the length of the green compact (and, thus, increasing the L/D ratio) causes an increase in the pressure losses caused by overcoming friction and requires higher compaction pressure.

\section{Results}

The selected SEM images of the composites reinforced with different types of SiC particle sizes (with addition of 2.5 and $7.5 \mathrm{wt} \%$ of $\mathrm{SiC}$ ) are presented in Figures 2 and 3. The silicon carbide reinforcing phase is located on the grain boundaries. Some agglomerations of the reinforcing phase formed during preparation in those composites reinforced with fine-grained $\mathrm{SiC}$ particles $(2 \mu \mathrm{m})$ were also observed (Fig. 2). The fine particles of reinforcement are located between the larger particles of aluminum.

One of the main factors decisive for the homogeneity of the reinforcing phase distribution in composites is the matrix-to-reinforcement PSR. The small ratio between the matrix and reinforcement particle size allows us to obtain a more-uniform distribution of the strengthening phase in the matrix. The growth in the PSR results in the agglomeration formation of $\mathrm{SiC}$ particles and a porosity increase. To improve the homogeneity of the distribution, it is suggested to use the larger-particle size of reinforcement. However, it should be mentioned that, on the other hand, increasing the reinforcement particle 
size might also cause the deterioration of mechanical properties due to lower work hardening and higher damage accumulation rates [7]. Therefore, it is important to properly select the size ratio between the matrix and reinforcement particle size. Figure 3 shows that applying a larger particle size of $\mathrm{SiC}(40-60 \mu \mathrm{m})$ and, thus, reducing the differences in the matrix/reinforcement PSR allowed us to obtain a more-uniform distribution of the reinforcement in the matrix.

a)

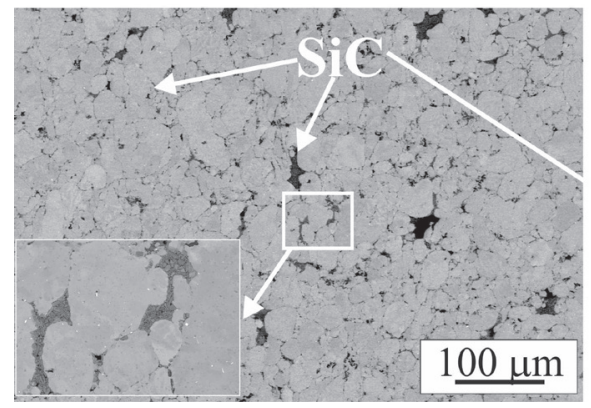

b)

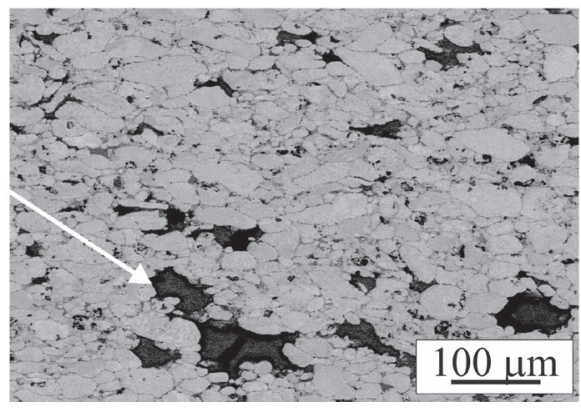

Fig. 2. SEM images of Al-MMCs for 2- $\mu$ m SiC size with: a) 2.5; b) $7.5 \mathrm{wt} \%$ of SiC

a)

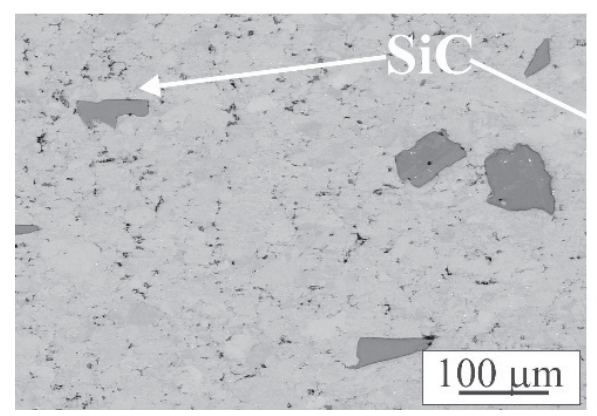

b)

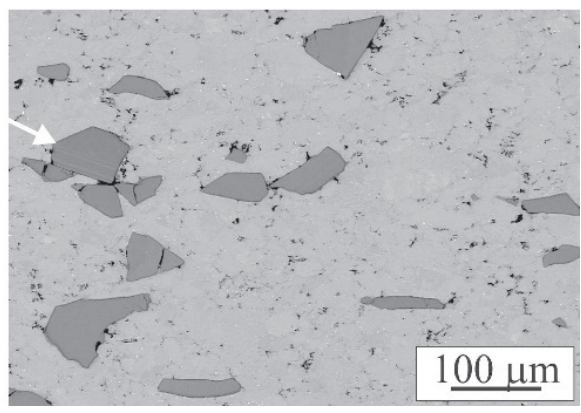

Fig. 3. SEM images of Al-MMCs for 40- to 60- $\mu$ m SiC particle size with: a) $2.5 ;$ b) $7.5 \mathrm{wt} \%$ of SiC

Figure 4 shows the effect of the $\mathrm{SiC}$ reinforcement particle size and its weight fraction on the densification of $\mathrm{Al}-\mathrm{SiC}$ composites. Decreasing the matrix to reinforcement PSR through increasing the particle size of the silicon carbide particles from 40 to $60 \mu \mathrm{m}$ increases the densification of Al-SiC. The main reason is the lower surface free energy of the coarser particles resulting from their lower total specific surface area than that of the finer particles [7]. Thereby, the powder compressibility for the larger particle size of reinforcement is higher, which allows for better densification. The highest compressibility has pure aluminum; therefore, its densification will be the greatest. However, the degree of compaction in Al-SiC composites with low PSR ratio remains at the same level; only 
a slight decrease for the content of $10 \mathrm{wt} \%$ of $\mathrm{SiC}$ can be noticed. It could be seen that, in the composites reinforced with the finer particle size of SiC $(2 \mu \mathrm{m})$, densification decreases as the content of reinforcement increases. As mentioned earlier, the formation of clusters in the empty spaces between aluminum particles during the sintering process leads to a decline in densification.

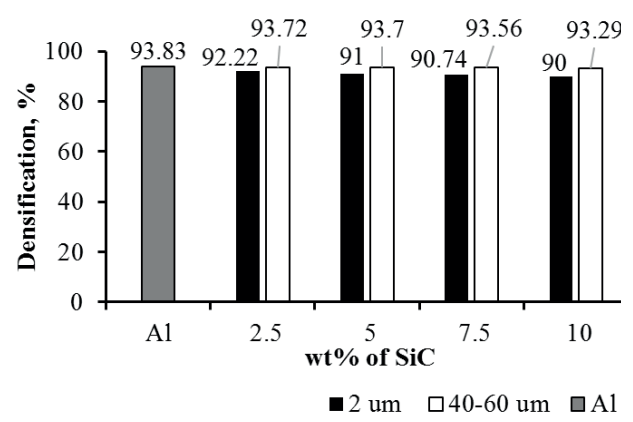

Fig. 4. Effect of SiC particle size and weight fraction on densification of Al-SiC composites

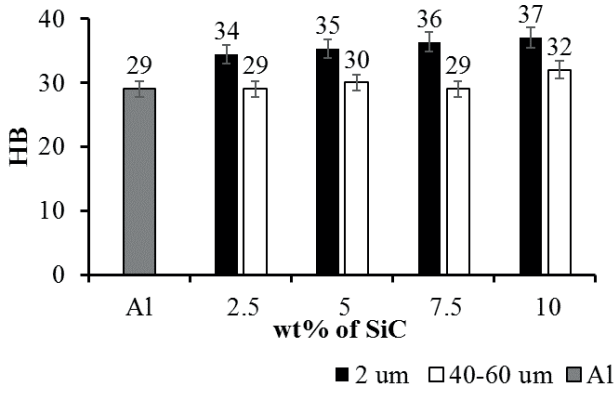

Fig. 5. Effect of SiC particle size and weight fraction on hardness of Al-SiC composites

The Brinell hardness results of the Al-SiC composites are illustrated in Figure 5. The addition of $\mathrm{SiC}$ particles into the aluminum matrix allowed for an increase in hardness. Increasing the reinforcing phase content with a particle size of $2 \mu \mathrm{m}$ to $10 \mathrm{wt} \%$ causes a hardness increase from 29 to $37( \pm 1.2) \mathrm{HB}$. By increasing the SiC phase content in the matrix, hardness also increased, but at the expense of its ductility $[1,5,7,8]$. This effect is less visible for the composites with the addition of reinforcements with particle sizes ranging between 40 and $60 \mu \mathrm{m}$, for which (at a lower SiC particle content) hardness remains almost at the same level and increased after exceeding the $10 \mathrm{wt} \%$ of $\mathrm{SiC}$ and was equal to $32 \mathrm{HB}$. The presence of $\mathrm{SiC}$ particles in the aluminum matrix generates the formation of dislocation at the Al matrix/SiC particles phase boundary in the form of dislocation loops, inhibiting the mobility of the subsequent dislocations during plastic deformation and, thus, resulting in the strengthening of the composite material $[9,10]$. Applying the fine fraction of $\mathrm{SiC}$ particles $(2 \mu \mathrm{m})$ resulted in obtaining higher values of hardness than after reinforcing the aluminum matrix by the larger particle sizes of $\mathrm{SiC}$ (40 to $60 \mu \mathrm{m}$ ). Decreasing the reinforcement particle size increases the hardness due to the fact that it is also correlated with increases in the interfacial area between the hard and soft phases, so more loads could be transferred from the matrix to the reinforcement particles. Furthermore, coarse-grained particles might have many defects, such as fractures, voids, and stress concentration; thus, they are more likely to fracture under tension than the finer ones. The coarse fraction of $\mathrm{SiC}$ particles that might have fractures and cause the voids cannot resist any load and act as potential areas for crack initiation points and, in this case, cause a degradation of the mechanical properties [1]. 
Figure 6 shows the stress-strain curve behavior of Al $+7.5 \mathrm{wt} \%$ of SiC (Fig. 6a) and $\mathrm{Al}+10 \mathrm{wt} \%$ of SiC (Fig. $6 \mathrm{~b}$ ) obtained from the compression test (these depend on the particle size of the reinforcing phase). The size of the reinforcement has a strong influence on the character of the curves. In both cases, higher strength was only obtained for the composites reinforced with a 2- $\mu \mathrm{m}$ particle size and reached $322 \mathrm{MPa}$ for the addition of $7.5 \mathrm{wt} \%$ of $\mathrm{SiC}$ and $335 \mathrm{MPa}$ for $10 \mathrm{wt} \%$ of SiC. For coarser particle reinforcement $(40-60 \mu \mathrm{m})$, the strength was lower (approx. $235 \mathrm{MPa}$ ) than for the pure aluminum matrix (290 MPa). Increasing the SiC particle size caused the mechanical properties to deteriorate due to the lower work hardening. The reinforcement particle size affects the movement of the dislocations. For the same reinforcing phase content, the number of $\mathrm{SiC}$ particles increases with the reduction of the particle size of the reinforcement. Therefore, dislocation strengthening is higher for the finer particles of the reinforcement [11]. The coarse fraction of $\mathrm{SiC}$ particles might also act as a potential region for a crack initiation point and, thus, cause the mechanical performance to degrade.

a)

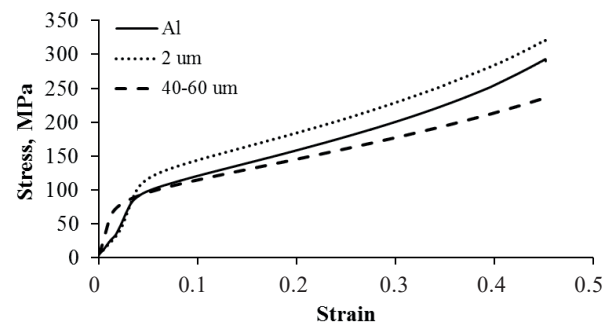

b)

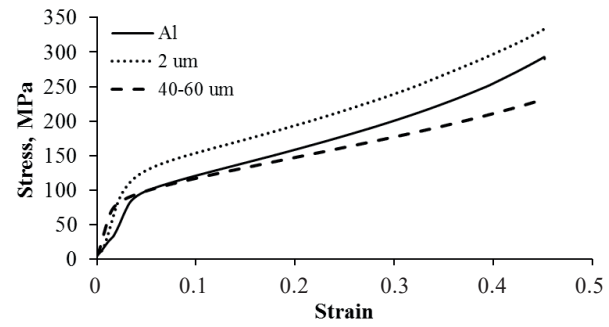

Fig. 6. Effect of SiC particle size on stress-strain curve behavior of Al-SiC composites reinforced with: a) $7.5 \mathrm{wt} \%$ of $\mathrm{SiC}$; b) $10 \mathrm{wt} \%$ of SiC

Figure 7 illustrates images of the samples after compression tests on the Al matrix reinforced with $10 \mathrm{wt} \%$ of $\mathrm{SiC}$ (dependent on the particle size of reinforcement). Numerous cracks and chipping on the surface of the samples can be observed. However, they are more visible for composites reinforced with coarser fractions of $\mathrm{SiC}$, for which the surface has been crushed.

a)

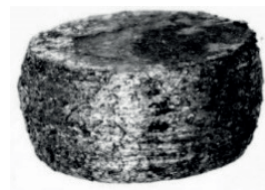

b)

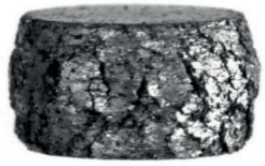

Fig. 7. Images of the samples after compression test for the addition of $10 \mathrm{wt} \%$ of SiC with particle sizes of: a) $2 \mu \mathrm{m}$; b) 40-60 $\mu \mathrm{m}$ 
Variation in compressive strength and yield stress of the Al-SiC composites dependent on the particle size and weight fraction are presented in Figure 8. As can be seen, the compressive strength increased from around $290 \mathrm{MPa}$ to $335 \mathrm{MPa}$, corresponding to the pure matrix and the matrix reinforced with $10 \mathrm{wt} \%$ of $\mathrm{SiC}$, respectively (but only for fine $\mathrm{SiC}$ powder particle size) (Fig. 8a). For the lower content of fine-grained SiC particles in the matrix, the compressive strength remains almost at the same level and increased after exceeding $5 \mathrm{wt} \%$ of the reinforcing phase up to $10 \mathrm{wt} \%$ of SiC. The compressive strength of the composite materials reinforced with coarse $\mathrm{SiC}$ particles seem not to be improved by $\mathrm{SiC}$ particle reinforcement, as it decreased by approximately $60 \mathrm{MPa}$ after the addition of reinforcing particles (and remained at the same lower level regardless of the weight fraction of the $\mathrm{SiC}$ particles). A similar trend can be observed in the yield stress (Fig. 8b). As mentioned earlier, inserting the SiC particles into the pure aluminum matrix generates the formation of dislocations at the interface between the reinforcement and matrix. The dislocation density increases with an increase in the SiC particle content; thereby, the strength of the composites grows. The effect of the introduced SiC reinforcing particles on the movement of the dislocations depends on their size. The reinforcement in the form of fine uniformly-distributed particles will block dislocation motion and, thus, strengthen the material. By increasing the weight fraction of $\mathrm{SiC}$ particles, the distance between them is reduced, thus increasing mechanical strength [12].

a)

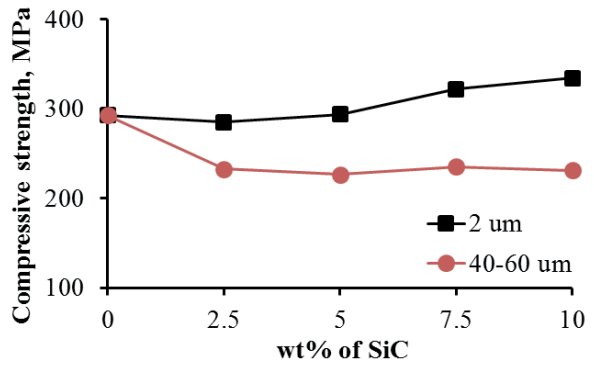

b)

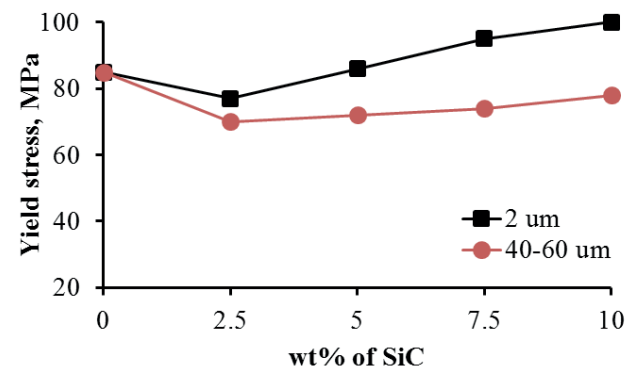

Fig. 8. Effect of SiC particle size and weight fraction on: a) compressive strength; b) yield stress of Al-SiC composites

\section{Conclusions}

The present study shows the dependence of the reinforcing phase on the mechanical properties of aluminum matrix composites. The following conclusions can be drawn:

1. The low value of PSR, achieved by the increase of particle size of reinforcement (from $2 \mu \mathrm{m}$ to $40-60 \mu \mathrm{m}$ ) has shown a relatively more-uniform distribution of SiC particles in the aluminum matrix. 
2. The densification of the composites increases with a decrease in the particle size ratio (PSR).

3. By increasing the weight fraction and decreasing the particle size of the $\mathrm{SiC}$ phase, hardness has been improved.

4. The yield stress and compressive strength of Al-SiC composites increases after introducing finer particles in the reinforcement phase.

\section{Acknowledgements}

The financial support of the Polish State Committee for Scientific Research under the grant number 11.11.180.653 is kindly acknowledged

\section{References}

[1] Duosheng Li, Yingwei Yu, Qing H.Qin, Xianliang Zhou, Aihua Zou, Xiaozhen Hua, Jianyun Zhang, Wenzheng Wu: Size Effect of SiC Particle on Microstructures and Mechanical Properties of SiCp/AI Composites. Proceedings of Fourth International Conference of Smart Materials and Nanotechnology in Engineering, Gold Coast, Australia, July 10, 2013, 8793, 879311

[2] Yueguang Wei: Particulate size effects in the particle-reinforced metal-matrix composites, Acta Mechanica Sinica, 17, 1 (2001), 45-58

[3] Ogel B., Gurbuz R.: Microstructural characterization and tensile properties of hot pressed Al-SiC composites prepared from pure Al and Cu powders. Materials Science and Engineering A, 301 (2001), 213-220

[4] Cerit A.A., Karamis M.B., Nair F., Yildizli K.: Effect of reinforcement particlae size and volume fraction on wear behavior of metal matrix composites. Tribology in Industry, 30, 3-4(2008), 31-36

[5] El-Kady O., Fathy A.: Effect of SiC particle size on the physical and mechanical properties of extruded Al matrix nanocomposites. Materials and Design, 54 (2014), 348-353

[6] Spowart J., Maruyama B., Miracle D.: Method for improving tensile properties of AISiC composites. United States Patent 6.12.2005, US 6972109 B1

[7] Fathy A., Sadoun A., Abdelhameed M.: Effect of matrix/reinforcement particle size ratio (PSR) on the mechanical properties of extruded Al-SiC composites. International Journal of Advanced Manufacturing Technology, 73, 5 (2014), 1049-1056

[8] Jamaati R., Amirkhanlou S., Toroghinejad M.R., Niroumand B.: Effect of particle size on microstructure and mechanical properties of composites produced by ARB process. Material Science and Engineering A, 528 (2011), 2143-2148

[9] Siva Prasad D., Chintada S.: Experimental evaluation onto the damping behavior of Al/SiC/RHA hybrid composites. Journal of Materials Research and Technology, 178 (2015), 1-8

[10] Chandrasekhar G.L., Vijayakumar Y., Nagaral M.: Investigations on Mechanical Properties of Al-4.5\% $\mathrm{Cu}-\mathrm{SiC}$ and $\mathrm{Al}-4.5 \% \mathrm{Cu}-\mathrm{Graphite}$ Composites. European Journal of Engineering Research and Science, 1, 1 (2016), 30-33

[11] Parvin N., Rahimian M.: The characteristics of alumina particle reinforced pure Al matrix composite. Acta Physica Polonica A, 121 (2012), 108-110

[12] Aribo S., Omotoyinbo J.A., Folorunso D.P.: High Temperature Mechanical Properties of Silicon Carbide Particulate Reinforced Cast Aluminium Alloy Composite. Leonardo Electronic Journal of Practices and Technologies, 18 (2011), 9-16 